\title{
AKIBAT HUKUM PERJANJIAN HUTANG PIUTANG DENGAN PERSYARATAN DOKUMEN PALSU (STUDI KASUS PENGADILAN NEGERI DENPASAR)
}

\author{
Putu Dila Parmila, I Nyoman Putu Budiartha, Ni Gusti Ketut Sri Astiti \\ Fakultas Hukum Universitas Warmadewa, Denpasar-Bali \\ dilaparmila25@gmail.com, budiartha.fhwjurnal@gmail.com, notarisppatsriastiti@yahoo.com
}

\begin{abstract}
Abstrak
Korupsi sudah menjadi tindak pidana yang sangat luar biasa, karena keberadaannya sangat mepengaruhi pertumbuhan perekonomian di Indonesia, dan banyak faktor yang mempengaruhi Tipikor (Tindak Pidana Korupsi) ini dapat terjadi karena adanya wewenang yang dimiliki terdakwa sehingga sangat mudah untuk melancarkan aksinya. Banyak cara yang dilakukan dalam menjalankan korupsi ini, salah satunya dengan melakukan pemalsuan dokumen ataupun surat-surat yang digunakan untuk syarat melakukan perjanjian utangpiutang. Rumusan masalah dalam penelitian ini yaitu apa akibat hukum perjanjian hutang piutang dengan persyaratan dokumen palsu dan apa faktor-faktor terjadinya perjanjian hutang-piutang dengan persyaratan dokumen palsu dan alur penyelesaian. Metode yang digunakan adalah normative. Berdasarkan hasil analisis data diperoleh hasil penelitian yaitu: Pencairan dana yang diakibatkan denan pemalsuan data atau dokumen Maka dari itu dapat ditarik kesimpulan bahwa terdakwa tidak akan dipidana dengan pasal pemalsuan, melainkan didakwakan melakukan tindak pidana korupsi karena akibat dari yang ia lakukan adalah terjadinya kerugian aset negara, selanjutnya Faktor yang mempengaruhi terjadinya tindak pidana korupsi paling utama adalah itikad tidak baik dari terdakwa sendiri, selanjutnya juga dari faktor wewenang yang ia miliki, sehingga ia dapat menggunakan kesempatan tersebut untuk melangsungkan tindakannya.
\end{abstract}

Kata Kunci: Perjanjian utang-piutang; Pemalsuan dokumen

\begin{abstract}
Corruption has become an extraordinary crime, because its existence greatly affects economic growth in Indonesia. There are many factors that influence the criminal acts of corruption to occur; usually because the perpetrator has the authority so it is very easy to carry out the action. There are many ways to carry out this corruption, one of which is by falsifying documents that are used as conditions for conducting debt-receivables agreements. The objects that this research examines are the legal consequences of the accounts payable agreement with the requirements for false documents and the factors of the occurrence of the accounts payable agreement with false document requirements and settlement flow. The method used to examine these two issues is the normative legal research method. Based on the results of data analysis, it was found that: disbursement of funds resulting from falsification of data or documents indicated that the defendant would not be convicted of the forgery article, but was charged with committing a criminal act of corruption because the result of his action was loss of state assets; The main factor affecting the occurrence of a criminal act of corruption is the bad faith of the defendant himself and also from the factor of authority he is being granted, so that he can make use of the opportunity to carry out his actions.
\end{abstract}

Keywords: Legal Consequence, Account Receivable Purchasing Agreement, Document Forgery

\section{PENDAHULUAN}

Manusia adalah makhluk sosial dimana selalu memerlukan orang lain untuk menjalankan kehidupannya, banyak aspek yang mempengaruhi manusia menjadi makhluk sosial, baik dalam segi budaya, hukum, begitu pula dalam kehidupan berekonomi. Untuk memenuhi kehidupannya, manusia perlu memenuhi kebutuhannya, salah satunya dalam bidang perekonomian. Banyak cara yang tersedia, antara lain berdagang, sewa-menyewa, dan yang paling sering terjadi adalah pinjam 
meminjam atau yang lebih sering kita sebut dengan hutang piutang. Jaman sekarang ini kegiatan hutang-piutang tidak hanya dilakukan bersama kerabat, teman ataupun keluarga. Sekarang sudah banyak lembaga yang menawarkan jasa pinjaman uang yang sekarang kita kenal dengan sebutan pinjaman kredit. Dalam penyaluran kredit pasti diawali dengan adanya perjanjian hutang piutang antara pihak kreditur dengan pihak debitur, dalam perjanjian tersebut harus ada kesepakatan antara kedua belah pihak sehingga dapat melaksanakan hak dan kewajibannya secara beriringan. Pada umumnya hak dan kewajiban yang lahir dari perikatan dipenuhi oleh pihak-pihak baik kreditur maupun debitur (Bandem et al., 2020).

Perjanjian ini dibuat untuk menghindari terjadinya wanprestasi antara kedua belah pihak, dan sama-sama mendapat perlindungan hukum. Dalam prosesnya debitur wajib memberikan dokumendokumen yang diperlukan dalam penyaluran kredit, sehingga petugas dari penyalur kredit dapat memproses kredit tersebut sebelum pemberian kredit kepada debitur terdahulu pemberian kredit wajib didasarkan pada prinsip kehatihatian yaitu harus bertindak hati-hati dalam menentukan siapa yang patut untuk diberikan kredit dan berapa besarnya jumlah kredit yang diberikan setelah mengetahui jaminan yang diberikan oleh calon debitur selanjutnya pihak pemberi kredit menjaga bahwa perjanjian yang dibuat dengan calon debitur tidak cacat dan memenuhi syaratsyarat sah perjanjian (Oktafiani \& Idris, 2015).

Dalam implementasinya masih saja banyak pihak yang menyalahgunakan kewenangannya untuk menguntungkan diri sendiri. Hal ini bisa saja terjadi akibat kurangnya kehatihatian dalam pemeriksaan keaslian dokumen dari yang mengajukan pinjaman. Menurut (Putra, 2018), terjadinya kredit fiktif karena faktor internal seperti pemberian kredit yang belum efektif, pengadministrasian yang tidak teratur/lemahnya sistem informasi seperti kelalaian pegawai dalam melakukan proses pemerikasaan tingkat keaslian dokumen sampai pada pemberian kredit. seperti halnya dari kasus yang peneliti dapatkan di Pengadilan Negeri Denpasar. Terdakwa sebagai AO yang memiliki wewenang untuk mengelola dokumen-dokumen milik debitur, ia menyalahgunakan dokumen itu untuk mencari kredit kembali di bank BRI dengan cara membuat kredit fiktif dengan memanfaatkan dokumen-dokumen debitur yang tercatat, melakukan perubahan data identitas debitur (seperti nama, NIK, alamat, tempat tanggal lahir,dll) seolah-olah merupakan calon debitur baru Briguna, membuat permohonan kredit atas nama debitur dan menandatangani sendiri seluruh berkas keperluan persyaratan pengajuan kredit Briguna, melakukan analisis kredit dan entry data calon debitur sendiri, melengkapi seluruh dokumen permohonan kredit dengan mengambil dokumen debitur lama, dan memalsukan tanda tangan debitur yang ada pada surat-surat, kwitansi dan datadata lain yang mengatasnamakan debitur tersebut. Namun dalam penyaluran dananya diambil langsung oleh terdakwa dengan dalih akan langsung diserahkan kepada debitur. Kemudian pada akhirnya saat dilakukan Special Audit (audit khusus) oleh Kantor Inspeksi Satuan Pengawasan Internal (SPI) Kantor Inspeksi BRI Denpasar pada bulan Desember 2015, sehingga terlihatlah kejanggalan dari kredit-kredit fiktif tersebut dan dibawalah kasus ini ke ranah kepolisian untuk diusut, dan ditemukanlah bukti bahwa terdakwa telah melakukan tindakan menyimpang dalam penyaluran kredit. Menurut (Redha Anshari, 2016), apabila dalam perkara kepailitan ditemukan kecurangan oleh kreditur maupun debitur, maka kreditur atau debitur tersebut dapat dikenakan sanksi pidana sesuai dengan KUH Pidana. Tujuan penelitian ini adalah Untuk mengetahui akibat hukum perjanjian hutang piutang dengan persyaratan dokumen yang sengaja dipalsukan. Yang kedua untuk mengetahui faktor-faktor dan alur penyelesaian perjanjian hutang piutang dengan persyaratan dokumen palsu.

\section{METODE PENELITIAN}

Penelitian ini menggunakan metode penelitian normatif, yaitu dengan cara menggali informasiinformasi yang ada pada literatur, dokumen-dokumen resmi seperti putusan pengadilan yang berhubungan dengan kasus yang dihadapi peneliti. Sumber data yang digunakan adalah sumber data primer dan sekunder. Bahan primer yaitu bahan hukum yang mempunyai kekuatan mengikat, misalnya peraturan perundang-undangan. Bahan ini diperoleh dari norma-norma dasar yaitu Kitab Undang-Undang Hukum Pidana (KUHP), Undang-undang Republik Indonesia Nomor 10 Tahun 1998 Tentang Perubahan Atas Undang-Undang Nomor 7 Tahun 1992 Tentang Perbankan, Kitab Undang-Undang Hukum Perdata (KUHPer) dan Putusan Pengadilan Negeri Denpasar Nomor 1786K/PID.SUS/2017. Sedangkan data sekunder yaitu bahan hukum yang bersumber pada 
keputusan, literatur-literatur, dokumen- dokumen yang bersangkutan dengan permasalahan yang dihadapi, dan artikel- artikel yang ada di Internet (Artikel Hukum). Pengumpulan bahan hukum primer dan sekunder ini dilakukan dengan cara mengembangkan dokumen-dokumen yang berhubungan dengan permasalahan yang dihadapi. Analisis data dilakukan dengan cara deskriptif analisis, dimana untuk memperoleh gambaran tentang status gejala, data-data yang diperoleh dari penelitian ini merupakan hasil pengamatan, hasil wawancara, pemotretan, cuplikan tertulis dari dokumen dan catatan lapangan.

\section{HASIL DAN PEMBAHASAN}

\section{Akibat Hukum Perjanjian Hutang-Piutang dengan Persyaratan Dokumen Palsu}

Hutang merupakan suatu kewajiban yang harus dibayarkan yang timbul akibat dari suatu perjanjian ataupun undang-undang, sedangkan piutang adalah suatu hak yang dimiliki seorang debitur atas apa yang dijanjikan oleh kreditur. Secara umum perjanjian hutang piutang diatur dalam pasal 1754 KUHPerdata, dimana pasal tersebut menyebutkan bahwa perjanjian hutang piutang adalah perjanjian dengan mana pihak yang satu memberikan kepada pihak yang lain suatu jumlah tertentu barangbarang yang menghabis karena pemakaian, dengan syarat bahwa pihak yang belakangan ini akan mengembalikan sejumlah yang sama dari macam dan keadaan yang sama pula. Dalam melaksana kan perjanjian hutang piutang ini ada pula syarat-syarat yang harus dipenuhi agar perjanjian tersebut sah di mata hukum. Syarat-syarat sahnya suatu perjanjian, antara lain: (a) Adanya kata sepakat antara dua belah pihak; (b) Para pihak yang melakukan perjanjian harus cakap dalam melakukan perbuatan hukum; (c) Perjanjian yang dilakukan harus berisikan objek perjanjian; (d) Perjanjian yang dilakukan harus berdasarkan sebab yang hala atau dalam kata lain perbuatannya tidak melanggar peraturan.

Supaya perjanjian menjadi sah maka para pihak harus sepakat terhadap segala hal yang terdapat di dalam perjanjian dan memberikan persetujuannya atau kesepakatannya jika ia memang menghendaki apa yang disepakati $(\mathrm{J}, 1995)$. Jadi dalam penelitian ini diambil suatu contoh tindak kejahatan yang dilakukan oleh seorang pegawai Bank yang dimana dia memalsukan dokumendokumen yang dijadikan persyaratan dalam pengajuan kredit atau dalam kata lain disebut juga kredit fiktif. Terdakwa melakukan kejahatannya tersebut dengan cara memalsukan keteranganketerangan seperti alamat, tempat dan tanggal lahir bahkan sampai tanda tangan debitur. Dokumendokumen yang dipalsukan tersebut didapat dari dokumen persyaratan kredit yang telah selesai atau sudah dilunasi, dimana terdakwa diam-diam memperbanyak dokumen-dokumen yang digunakan dalam pemberian kredit sebelumnya. Dan menggunakan dokumen-dokumen atau surat tersebut untuk melancarkan tindakannya. Surat yang dimaksud dalam bab ini adalah segala surat, baik yang ditulis dengan tangan, dicetak, maupun ditulis memakai mesin tik, dan lain-lainnya (R, 1980).

Dalam penanganan kasus ini terjadi kekaburan norma, apakah terdakwa akan diadili secara pidana pemalsuan atau tindak pidana korupsi. Jadi hal ini dapat ditentukan dari akibat hukum yang dihasilkan dari peristiwa ini. Sehingga perlu diklasifikasikan lebih terperinci dari segi pidana pemalsuan dan tindak pidana korupsi. Dalam pasal 3 UU No.31 Tahun 1999 menjelaskan Setiap orang yang dengan tujuan menguntungkan diri sendiri atau orang lain atau suatu korporasi, menyalahgunakan kewenangan, kesempatan atau sarana yang ada padanya karena jabatan atau kedudukan yang dapat merugikan keuangan negara atau perekonomian negara, dipidana dengan pidana penjara seumur hidup atau pidana penjara paling singkat 1 (satu) tahun dan paling lama 20 (dua puluh) tahun dan atau denda paling sedikit Rp. 50.000.000,00 (lima puluh juta rupiah) dan paling banyak Rp. 1.000.000.000,00 (satu milyar rupiah). Sedangkan dalam pasal 263 Kitab Undang-Undang Hukum Pidana merumuskan sebagai berikut: "barangsiapa membuat surat palsu atau memalsukan surat yang dapat menimbulkan suatu hak, perikatan atau pembebasan hutang, atau yang diperuntukkan sebagai bukti dari pada sesuatu hal yang dengan maksud untuk memakai atau menyuruh orang lain memakai surat tersebut seolah-olah isinya benar dengan dipalsu, diancam jika pemakaian tersebut dapat menimbulkan kerugian, karena pemalsuan surat, dengan pidana penjara paling lama enam tahun." Dalam pasal ini dijelaskan mengenai tindak pidana pemalsuan surat pada umumnya, namun apabila dilihat dari tindak pidana dalam contoh kasus yang digunakan dalam penulisan penelitian ini, tindakannya mengarah ke Pasal 264 Kitab Undang-Undang Hukum Pidana yaitu pemalsuan surat yang diperberat. Dalam pasal ini merumuskan: "pemalsuan surat diancam dengan pidana penjara paling lama delapan tahun, jika dilakukan terhadap: 
1. Akta-akta otentik;

2. Surat hutang atau sertifikat hutang

3. Surat sero atau hutang atau sertifikat sero atau hutang

4. Talon, tanda bukti dividen atau bunga dari salah satu surat yang diterangkan dalam 2 dan 3 , atau tanda bukti yang dikeluarkan sebagai pengganti surat-surat itu;

5. Surat kredit atau surat dagang yang diperuntukkan untuk diedarkan".

Jika dilihat dari perumusan delik tindak pidana pemalsuan surat yang diperberat (pasal 264

KUHP) harus juga dihubungkan dengan tindak pidana pemalsuan surat pada umumnya pasal 263 KUHP),karena unsur-unsurnya sama saja, namun pada objek surat-suratnya saja yang berbeda. Maka dari itu akibat hukum yang dihasilkan dari perjanjian hutang piutang dengan persyaratan dokumen palsu yaitu terjadinya kasus tindak pidana korupsi. Tindak pidana korupsi merupakan tindak pidana materiil, karena tindak pidana korupsi merupakan peristiwa yang dapat dikatakan tindak pidana karena ada akibat yang ditimbulkan dari peristiwa tersebut, akibat yang dihasilkan sudah pasti kerugian keuangan negara. Sehingga tindakan terdakwa yang diawali dengan memalsukan dokumen persyaratan milik nasabah berujung dengan timbulnya kerugian keuangan negara. Apabila ditelaah lagi mengenai unsur-unsur dari kedua tindak pidana ini, pasti akan lebih merujuk ke tindak pidana korupsi. Karena hasil dari perbuatan yang dilakukan terdakwa sudah mengakibatkan kerugian Negara yang cukup besar, sedangkan dalam unsur-unsur tindak pidana pemalsuan surat kurang dijelaskan mengenai akibat yang dihasilkan dari tindak pidana tersebut. Pada dasarnya tindak pidana pemalsuan juga termasuk dalam tindak pidana materiil. Karena dari unsur-unsur delik yang telah disebutkan yaitu berakibat timbulnya suatu hak, perikatan, pembebasan hutang, sebagai bukti dan dapat menimbulkan kerugian kepada orang lain, tindakan terdakwa sudah masuk ke semua unsur tindakan pemalsuan. Namun dalam kasus ini tindakan yang dilakukan atas pemalsuan tersebut berakibat terjadinya kerugian keuangan negara, sehingga karena dalam Undang-Undang No. 31 Tahun 1999 tentang Pemberantasan Tindak Pidana Korupsi mengatur lebih jelas mengenai kerugian keuangan negara, maka terdakwa diadili di Pengadilan dengan berpedoman pada UU Tipikor ini.. Jadi sudah dapat diklasifikasikan bahwa kasus yang digunakan sebagai contoh dalam penulisan skripsi ini diklasifikasikan ke dalam Tindak Pidana Korupsi dan diadili berpedoman pada UU NO.31 Tahun 1999 Tentang Pemberantasan Tindak Pidana Korupsi.

\section{Faktor-faktor Terjadinya Perjanjian Utang-Piutang dengan Persyaratan Dokumen Palsu dan Bagaimana Alur Penyelesaiannya}

Faktor-faktor yang mempengaruhi dapat terjadinya perjanjian utang piutang dengan persyaratan dokumen palsu, antara lain :

1. Adanya itikad buruk dari terdakwa sebagai pegawai penyalur kredit;

2. Pegawai dalam penyaluran kredit tidak melaksanakan tugas sesuai dengan standar operasional yang telah diterapkan oleh bank;

3. Adanya kesempatan akibat kelalaian pegawai lain, sehingga terdakwa dengan mudah menjalankan perbuatannya;

4. Kurangnya pengawasan dari pusat sehingga peristiwa ini terjadi begitu lama, dan menimbulkan kerugian yang sangat besar.

Dari faktor-faktor tersebut, dapat disimpulkan bahwa sangat riskan terjadinya Tipikor di berbagai bidang, karena hal ini sudah sangat mengganggu pertumbuhan ekonomi di Indonesia maka diperlukan banyak upaya guna menekan terjadinya kasus Tipikor. Salah satu cara yang dapat diambil adalah menuntut pertanggungjawaban atas kerugian negara yang dihasilkan. Ada dua jalur peradilan yang dapat ditempuh dalam menangani kasus Tipikor ini, yaitu jalur peradilan pidana dan jalur peradilan perdata. Fenomena ini dapat dimaklumi mengingat dampak negatif yang ditimbulkan oleh tindak pidana ini sehingga tindak pidana korupsi dikategorikan sebagai tindak pidana luar biasa (Extra Ordinary Crime), (Hartanti, 2007). Dalam proses peradilan pidana terdakwa akan diproses sesuai dengan Undang-Undang No.31 Tahun 1999 Tentang Pemberantasan Tindak Pidana Korupsi. Prosedurnya yaitu: (1) Penyelidikan, (2) Penyidikan para penuntutan dan Penuntutan, (3) Pembacaan surat dakwaan, (4) Eksepsi, (5) Pembuktian, (6) Pembacaan surat tuntutan, (7) Pledoi dan (8) Putusan hakim pengadilan. 
Namun apabila dilihat di kenyataannya dan dalam Undang-Undang No.31 Tahun 1999 disebutkan terdakwa hanya dipidana dengan pidana penjara paling singkat 1 (satu) tahun dan paling lama 20 (dua puluh) tahun dan atau denda paling sedikit Rp. 50.000.000,00 (lima puluh juta rupiah) dan paling banyak Rp. 1.000.000.000,00 (satu milyar rupiah), dimana hal tersebut tidak sebanding dengan julukan tipikor yang sudah masuk sebagai extraordinary crime. Yang dapat dihukum itu sebenarnya adalah manusia sebagai pribadi dan bukan kenyataan, perbuatan ataupun tindakan (Lamintang, 1997). Sehingga diperlukan langkah lebih lanjut untuk menuntut pertanggungjawaban atas kerugian negara, yaitu dengan menempuh jalur peradilan perdata. Dimana hal ini dapat dilakukan dengan bantuan Jaksa Pengacara Negara (JPN) sebagai pihak yang berwenang sebagai perwakilan negara atau pihak yang merasa dirugikan atas tipikor tersebut. Prosedur yang perlu ditempuh dalam peradilan Perdata, yaitu:

a) Pembacaan Gugatan.

b) Jawaban tergugat.

c) Tanggapan penggugat.

d) Tahap pembuktian/jawab-menjawab.

e) Kesimpulan.

f) Putusan.

Dalam proses peradilan perdata ini sebenarnya sama saja seperti proses peradilan perdata pada umumnya, hanya saja disini yang berperan sebagai penuntut umum adalah Jaksa Pengacara Negara (Jaksa Pengacara Negara). Namun dalam proses peradilan perdata ini masih sangat tidak efektif, dimana proses peradilannya sangat bertentangan dengan asas peradilan yang sederhana, cepat dan biaya ringan. Karena proses ini masih sangat berbelit-belit. Terlebih lagi dalam prosedur pembuktiannya masih sangat memberatkan penggugat. Karena beban pembuktian diserahkan sepenuhnya kepada penggugat untuk menemukan bukti bahwa aset-aset yang dimiliki tergugat merupakan hasil dari korupsi. Dalam masalah pembuktian, pemerintah cukup menghitung berapa pendapatan yang layak bagi pelaku, kemudian membandingkan dengan aset yang dimiliki. Jika aset yang dimiliki melebihi jumlah pendapatannya, maka pelaku berkewajiban membuktikan bahwa aset tersebut diperoleh secara legal (Saputra, 2016). Maka dari itu, sangat diperlukan dibuatnya undangundang yang khusus membahas mengenai masalah ini, sehingga akan ada pedoman yang tepat dan tentu akan membantu menekan jumlah kasus korupsi di Indonesia.

\section{SIMPULAN DAN SARAN}

\section{Simpulan}

Akibat hukum yang ditimbulkan dari pemalsuan dokumen persyaratan pencairan kredit ini dapat dilihat dari akibat yang dihasilkan, dimana awalnya terdakwa melakukan pemalsuan dokumen-dokumen persyaratan tersebut guna membuat rekening fiktif sehingga dana nasabah itu diterima oleh dirinya sendiri. dari peristiwa tersebut akan berakibat terjadinya kerugian aset negara. Maka dari itu dapat ditarik kesimpulan bahwa terdakwa tidak akan dipidana dengan pasal pemalsuan, melainkan didakwakan melakukan tindak pidana korupsi karena akibat dari yang ia lakukan adalah terjadinya kerugian aset negara. Faktor yang mempengaruhi terjadinya tindak pidana korupsi paling utama adalah itikad tidak baik dari terdakwa sendiri, selanjutnya juga dari faktor wewenang yang ia miliki, sehingga ia dapat menggunakan kesempatan tersebut untuk melangsungkan tindakannya. Karena tindakan korupsi ini merupakan suatu tindak pidana luar biasa (extraordinary crime) maka, penyelesaian kasusnya juga harus dilakukan secara ekstra. Maka dapat diselesaikan dengan jalur perdata maupun pidana. Apabila dalam peradilan pidana sudah dijatuhkan hukuman, namun tidak ada pertanggungjawaban atas kerugian aset negara, maka dapat diambil langkah peradilan perdata dengan cara mengajukan gugatan melalui Jaksa Pengacara Negara. Namun, menempuh jalur perdata banyak mengalami kendala, seperti beratnya proses pembuktian, dimana pembuktian diberatkan kepada penggugat, sehingga akan memakan biaya yang banyak dan juga proses yang berbelit-belit.

\section{Saran}

Berdasarkan hasil penelitian diatas peneliti memberi saran yang pertama adalah Dalam menjatuhkan dakwaan sebelumnya harus diperhatikan dahulu dalil-dalil dari tindak pidananya. Sehingga tidak akan ada kesalahan dalam menjatuhkan hukuman terhadap terdakwa itu sendiri, karena apabila terdapat kesalahan dalam menjatuhkan hukuman yang tidak sesuai dengan dalil-dalil maka akan berakibat buruk 
bagi terdakwa ataupun korban. Sehingga tidak akan ada kekaburan norma dalam sistem hukum di Indonesia. Saran yang kedua bahwa Sebelum terjadinya tindak pidana, seharusnya suatu perusahaan selalu menggunakan standar operasi perusahaannya, sehingga tidak ada celah untuk oknum-oknum yang tidak bertanggung jawab untuk melakukan tindakan yang lebih buruk, apabila tindak pidana itu sudah terjadi maka, apabila akibat yang dihasilkan dari tindakan itu bersifat ekstra, maka penangannya harus dilakukan lebih ekstra.

\section{DAFTAR PUSTAKA}

Bandem, I. W., Wisadnya, I. W., \& Mordan, T. (2020). Akibat Hukum Perbuatan Wanprestasi dalam Perjanjian Hutang-Piutang. Raad Kertha, 03 (01), 1-21.

Hartanti, E. (2007). Tindak Pidana Korupsi (2nd ed.). Sinar Grafika.

J, S. (1995). Perikatan yang Lahir dari Perjanjian. Citra Aditya Bakti.

Lamintang, P. A. . (1997). Dasar-DAsar Hukum Pidana Indonesia Bandung. Citra Aditya Bakti.

Oktafiani, L., \& Idris, I. (2015). Pelaksanaan Pemberian Kredit dengan Jaminan Hak Tanggungan Pada Debitur PT. Bank DKI Jakarta Pusat. Lex Jurnalica, 12(2), 79-90.

Putra, S. K. (2018). Kajian Yuridis terhadap Piutang Tidak Tertagih atas Penjualan Produk Secara Kredit pada Badan Usaha Milik Negara (BUMN). Asy-Syariah, 20(1), 72-84.

R, S. (1980). Kitab Undang-undang Hukum Pidana (KUHP) serta Komentar-Komentarnya Lengkap Pasal Demi Pasal. Politeria.

Redha Anshari, M. (2016). Rekayasa Piutang oleh Kreditor untuk Memenuhi Persyaratan Permohonan Pernyataan Pailit. Lex Renaissance, 1(1), 126-138.

Saputra, R. (2016). Kewenangan Penuntutan Komisi Pemberantasan Korupsi (KPK) pada Kasus Tindak Pidana Pencucian Uang. Jurnal Hukum Respublica, 16(1), 103-119. 